\begin{tabular}{|c|c|c|c|c|}
\hline VOLUME & NOMOR & HALAMAN & JANUARI & ISSN \\
\hline VI & 1 & $1-64$ & 2018 & $2303-1859$ \\
\hline
\end{tabular}

\title{
JURNAL AKADEMIK
}

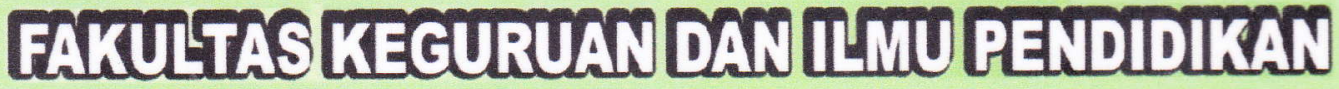

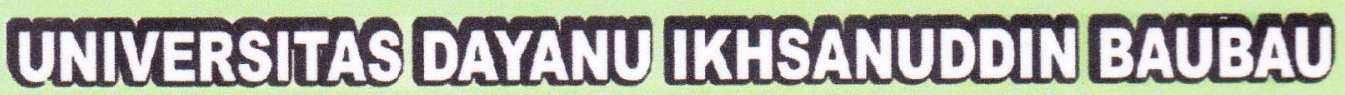

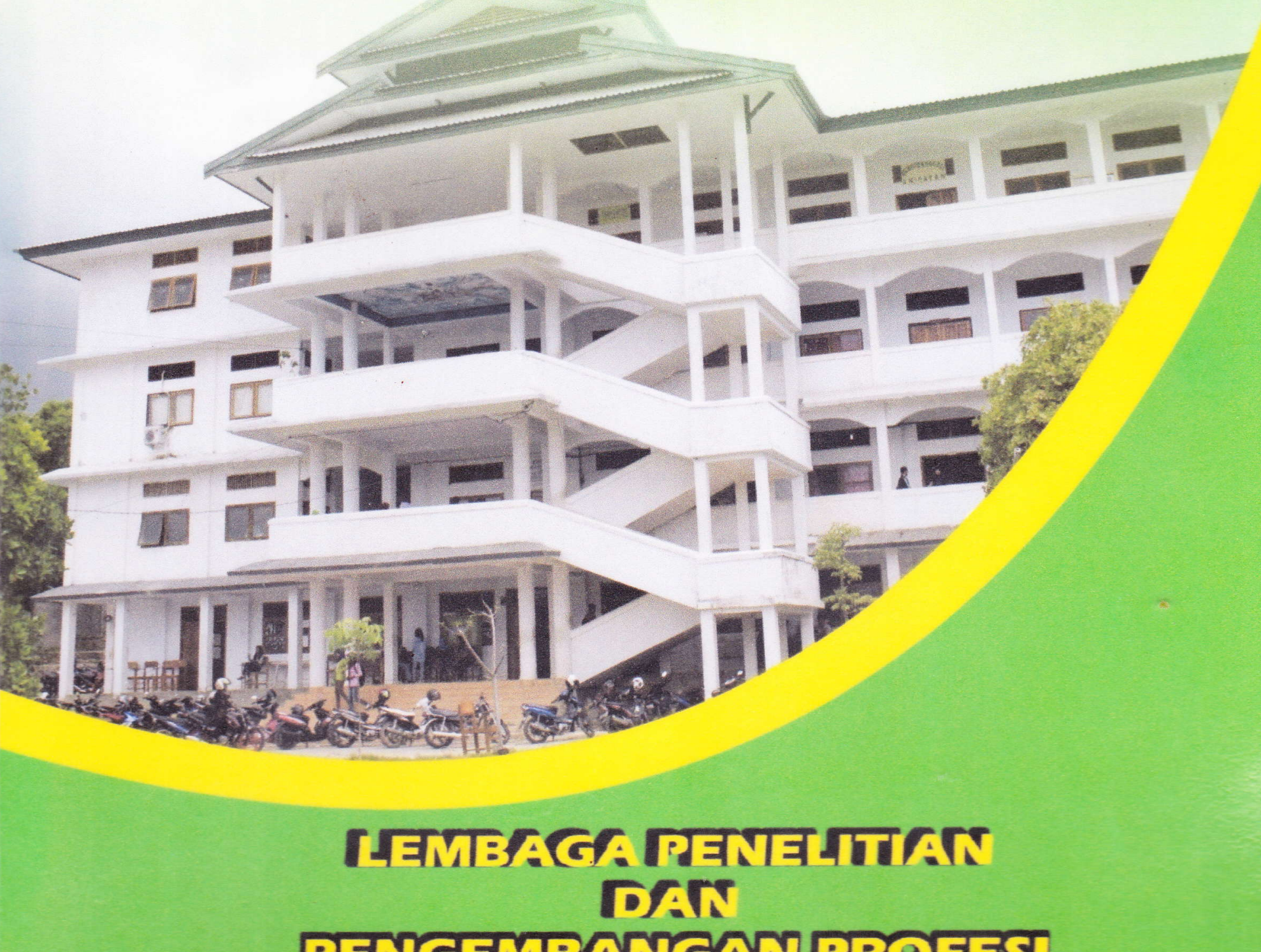




\title{
JURNAL AKADEMIK

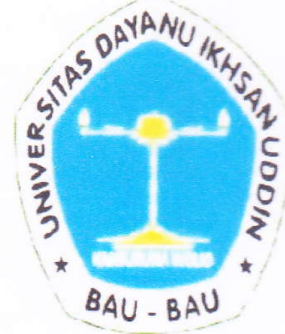

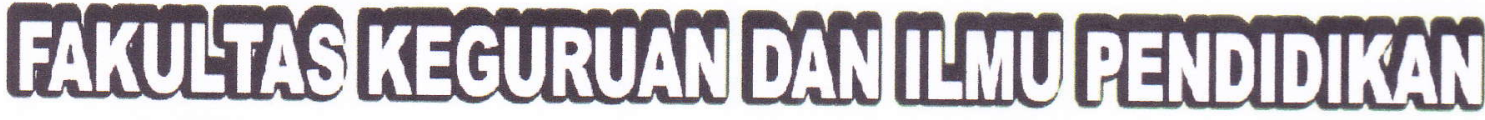

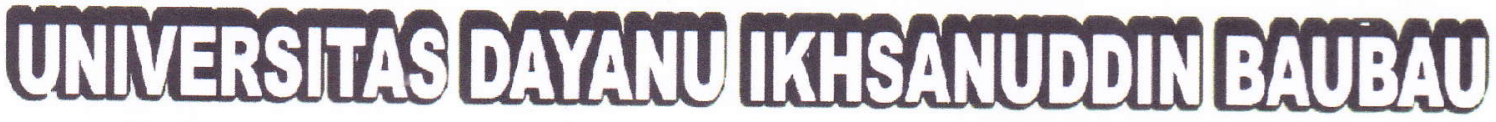

\author{
Pengaruh Pendidikan Karakter terhadap Hasil Belajar Matematika \\ Siswa Kelas X MIPA SMA Negeri 1 Pasarwajo \\ Anwar, Ernawati Jais dan Wa Ode Sabitri
}

Meningkatkan Hasil Belajar Bahasa Indonesia melalui Model Kooperatif Tipe Round Table

Siswa Kelas VIII SMP Satap SMP Negeri 1 Kulisusu

\section{Daazima}

Implementasi Metode Mind Mapping untuk Meningkatkan Kompetensi Writing di Kelas VIII SMPN 2 Wakorumba Utara

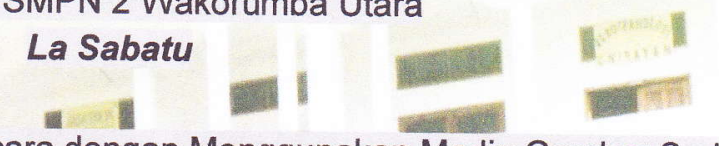

Peningkatan Kemampuan Berbicara dengan Menggunakan Media Gambar Seri

" pada Siswa Kelas VI SD Negeri 1 Bubu Tahun Pelajaran 2016/2017

\section{La Ntete}

Upaya Meningkatkan Prestasi Belajar Siswa dengan Menggunakan Model Pembelajaran

Quiz Team pada Mata Pelajaran PKN Siswa Kelas IX SMP Negeri 1 Wakorumba Utara
1
-1 1
Ramni
Penerapan Strategi Pembelajaran Think Talk Write (TTM) untuk Meningkatkan Hasil Belajar Bahasa Indonesia Siswa Kelas VI SD Negeri 1 Mata 


\title{
PENGARUH PENDIDIKAN KARAKTER TERHADAP HASIL BELAJAR MATEMATIKA SISWA KELAS X MIPA SMA NEGERI 1 PASARWAJO
}

\author{
${ }^{1)}$ Anwar, ${ }^{2)}$ Ernawati Jais dan ${ }^{3)}$ Wa Ode Sabitri \\ (1) \& 2)Dosen dan ${ }^{2)}$ Mahasiswa Program Studi Pendidikan Matematika FKIP Unidayan Baubau)
}

\begin{abstract}
The objective of this research was to find out whether the character education has significant influence on mathematics learning outcame at grade X MIPA students of SMA Negeri I Pasarwajo in school year 2017/2018. This research used ex-post facto design. The population in this research was the entire students of grade X MIPA of SMA Negeri 1 Pasarwajo that consisted of 205 students, and the sample was 60 students. The instruments in this research used questionnaire and documentation.

The finding showed that, (1) The character education level of grade A MIPA students of SMA Negeri I Pasarwajo was categorized moderate, it can be seen from 60 students, there were 9 students with high category (15\%), 42 students with moderate category (70\%) and 9 students with low category (15\%); (2) The level of students' mathematics learning outcame of grade X MIPA students of SMA Negeri 1 Pasarwajo was categorized moderate. It also can be seen from 60 students, there were 8 students in high category $(13,33 \%), 36$ students in moderate category $(60 \%)$ and 16 students low category (26,67\%); (3) The characters education had positif and significant influence toward students' mathematics achievement at grade X MIPA students of SMA Negeri 1 Pasarwajo which illustrated by linear regression equation $\widehat{Y}=55,355+0,295 X$.
\end{abstract}

Keywords: character education, Students' learning outcame, mathematics

\section{PENDAHULUAN}

Pendidikan pada hakekatnya adalah usaha untuk mengembangkan kepribadian dan kemampuan di dalam dan di luar sekolah yang berlangsung seumur hidup. Pendidikan nasional yang diselenggarakan oleh pemerintah maupun pihak swasta itu secara ideal diarahkan untuk membentuk warga Negara yang berkarakter, bertanggung jawab atas terselenggaranya masyarakat Indonesia yang adil dan makmur, baik spiritual maupun material. Hal ini tersirat dalam bunyi Pasal 3 Undang-Undang (selanjutnya disebut UU) Nomor (selanjutnya disebut No.) 20 tahun 2003 tentang Sistem Pendidikan Nasional.

Amanah Undang-Undang tersebut bermaksud bahwa pendidikan tidak hanya membentuk generasi yang cerdas, namun juga berkepribadian atau berkarakter. Hal ini juga pernah ditegaskan oleh Martin Luther King (dalam Jamal Ma'mur Asmani, 2013:25) "Intelligence plus character, that is the goal of true education" (Kecerdasan yang berkarakter adalah tujuan akhir pendidikan yang sebenarnya). Seiring dengan keadaan yang ada, lembaga pendidikan sebagai lembaga akademis yang mempunyai tugas menyelenggarakan pendidikan, ilmu pengetahuan, teknologi, dan seni. Seyogyanya dalam hal menyelenggarakan pendidikan tidak hanya menitikberatkan pada pengembangan ilmu pengetahuan, melainkan juga menanamkan sikap atau perilaku yang baik untuk membentuk kepribadian, kemandirian, keterampilan sosial, dan karakter. Theodore Rhoosevelt mengatakan (dalam Maya Umami, 2013:1) "To educate a person mind and not in morals is to educate a menace to society". (Mendidik seseorang dalam aspek kecerdasan otak dan bukan aspek moral adalah ancaman 
marabahaya bagi masyarakat). Dari pernyataan di atas maka perlu adanya keseimbangan antara
kecerdasan otak dan aspek moral.

Solusi bagi maraknya problem sosial yang menimpa bangsa ini, dan lembaga pendidikan harus tampil sebagai pionir pendididkan karakter guna membangun karakter anak didik yang bermoral, dan berakhlak, dinamis, serta visionir. Lembaga pendidikan harus bekerja sama dengan keluarga, masyarakat, dan elemen bangsa yang lain demi mensukseskan agenda besar menanamkan karakter kepada peserta didik sebagai calon penerus bangsa dimasa yang akan datang. Tentu dalam proses pelaksanaannya tak semudah membalikkan telapak tangan, akan banyak ditemukan tantangan dan hambatan yang harus dihadapi. Namun sekarang banyak elemen masyarakat menyadari betapa pentingnya menanamkan karakter kepada peserta didik sebagai calon penerus bangsa dimasa yang akan datang. Penanaman pendidikan karakter di dalam kurikulum sekolah merupakan amanat kebijakan yang telah dikeluarkan oleh Menteri Pendidikan Nasional dimana dalam hal ini adalah "pengintegrasian pendidikan karakter ke dalam kurikulum, mulai dari jenjang prasekolah, pendidikan dasar, pendidikan menengah baik pada jalur pendidikan formal maupun nonformal, hingga perguruan tinggi". (www.antaranews.com, diakses tanggal 15/5/2010 dalam Ovi Yuliana 2013:3). Dan pastinya tidak hanya mengharapkan penanaman karakter di dalam pendidikan formal, banyak dari masyarakat yang membuat kelompok-kelompok belajar (pendidikan nonformal) yang menanamkan pendidikan karakter pada siswa.

Pembelajaran matematika yang diberikan selama dua belas tahun dari sejak SD sampai dengan SMA dan dengan porsi jam pelajaran yang paling banyak, tentunya akan menjadi wahana yang tepat untuk memahatkan berbagai karakter pada peserta didik. Namun kenyataannya, selama ini guru belum bisa menumbuhkan karakter bagi siswa sehingga seperti pelaksanaan pembelajaran matematika guru cenderung mementingkan terjadi karena dalam psikomotorik, sedangkan aspek afektif guru cenderung mementingkan aspek kognitif dan 2013:7).

Pendidikan karakter memang bukan termasuk mata pelajaran tetapi sebagian diterapkan dalam proses pembelajaran atau bahkan di luar proses pembelajaran seperti berdo'a sebelum memulai pembelajaran, menyalami guru piket pada saat datang ke sekolah atau sebelum masuk kelas, shalat Dhuha saat istirahat pertama, dan shalat Dzuhur saat istirahat kedua.

Berdasarkan uraian di atas, maka rumusan masalah dalam penelitian ini adalah Apakah terhadap hasil belajar siswa kelas XMIPA SMA Negeri I Pasarwajo?

\section{METODE PENELITIAN}

Jenis penelitian ini menggunakan penelitisn ex post facto dan penelitian ini dilaksanakan pada semester genap Tahun Ajaran 2016/2017 bulan Mei 2017 di kelas X MIPA SMA Negeri 1
Pasarwajo yang bertempat di Kabupaten Buton.

Populasi dari penelitian ini adalah seluruh kelas X MIPA di SMA Negeri 1 Pasarwajo pada semester genap Tahun Ajaran 2016/2017 terdiri dari 6 kelas yaitu kelas X MIPAl, kelas X $\mathrm{MIPA}_{2}$. kelas X MIPA ${ }_{3}$ X MIPA 4 , X MIPA, dan X MIPA, X MIPA7, X MIPAs. Sampel 
dalam penelitian ini diambil hanya 3 kelas yakni X MIPA2, kelas X MIPA 3 . Dan kelas X MIPA4 dengan total jumlah sampel dalam penelitian ini berjumlah 60 orang.

Instrumen yang digunakan dalam penelitian ini adalah angket dan dokumentasi, dan data dalam penelitian ini dianalisis dengan menggunakan:

1. Analisis Deskriptif

Analisis deskriptif dimaksudkan untuk mendeskripsikan karakteristik dan masing-masing variabel penelitian dengan menggunakan rata-rata standar deviasi, nilai maksimum, median, nilai minimum kedalam bentuk tabel frekuensi dan persentase.

2. Analisis Statistik Inferensial

Analisis ini dimasukan untuk menguji hipotesis penelitian dengan menggunakan analisis regresi linear sederhana, dengan bentuk umum yaitu:

$$
Y=\alpha+\beta X+\varepsilon
$$

Dimana:

Dengan menghitung taksiran $\hat{Y}=a+b X$

$\mathrm{Y}=$ Variabel tak bebas

$\alpha, \beta=$ Parameter, dimana $\alpha$ konstanta regresi dan $\beta$ koefisien arah regresi

$\varepsilon \quad=$ Penyimpangan nilai Variabel Dependen terhadap garis regresinya

$\mathrm{a}=$ Taksiran dari $\alpha$

b $=$ Taksiran dari $\beta$

$\hat{Y} \quad=$ Variabel yang diprediksi

\section{HASIL PENELITIAN DAN PEMBAHASAN}

\section{A. Hasil Penelitian}

\section{Analisis Deskriptif}

\section{a. Deskriptif Hasil Angket Pendidikan Karakter}

Dari hasil analisis statistik deskriptif hasil angket pendidikan karakter pada siswa SMA Negeri 1 Pasarwajo menggunakan program SPSS 20 for windows. Berdasarkan hasil analisis diperoleh Mean $=100,0500$; Median = 100,0000; Modus $=110,00 ;$ Standar Deviasi $=11,14987 ;$ Varians $=123,319 ;$ Minimum $=64,00$; Maksimum = 122,00.

Untuk persentase skor pendidikan karakter siswa kelas X MIPA SMA Negeri 1 Pasarwajo berdasarkan hasil penelitian dapat dilihat pada Tabel 1 berikut ini:

Tabel 1. Deskripsi Pendidikan Karakter Siswa Kelas X MIPA SMA Negeri 1 Pasarwajo

\begin{tabular}{cccc}
\hline Interval Skor & Frekuensi & $\begin{array}{c}\text { Persentase } \\
(\%)\end{array}$ & Kategori \\
\hline $\mathrm{X} \geq 111,15$ & 9 & 15 & Tinggi \\
$88,85 \leq \mathrm{X}<111,15$ & 42 & 70 & Sedang \\
$\mathrm{X}<88,85$ & 9 & 15 & Rendah \\
\hline Jumlah & 60 & $\mathbf{1 0 0}$ & \\
\hline
\end{tabular}




\section{b. Deskriptif Hasil Belajar Matematika Siswa}

Dari hasil analisis statistik deskriptif prestasi belajar matematika pada siswa SMA Negeri 1 Pasarwajo menggunakan program SPSS 20 for windows. Berdasarkan hasil analisis diperoleh Mean $=84,9167 ;$ Median $=85,0000 ;$ Modus $=80,00 ;$ Standar Deviasi $=4,46186 ;$ Varians $=19,908 ;$ Minimum $=75,00 ;$ Maksimum $=97,00$.

Untuk persentase skor hasil belajar matematika siswa kelas X MIPA SMA Negeri 1 Pasarwajo berdasarkan hasil penelitian dapat dilihat pada Tabel 2 berikut ini.

Tabel 2. Deskripsi Hasil Belajar Matematika Siswa Kelas X MIPA SMA Negeri 1 Pasarwajo

\begin{tabular}{cccc} 
Interval Skor & Frekuensi & $\begin{array}{c}\text { Persentase } \\
(\boldsymbol{\%})\end{array}$ & Kategori \\
\hline $\mathrm{X} \geq 89,38$ & 8 & 13,33 & Tinggi \\
$80,46 \leq X<89,38$ & 36 & 60 & Sedang \\
$X<80,46$ & 16 & 26,67 & Rendah \\
\hline Jumlah & $\mathbf{6 0}$ & $\mathbf{1 0 0}$ & \\
\hline
\end{tabular}

\section{Analisis Statistik Inferensial}

\section{a. Menghitung Nilai Korelasi Tunggal}

Nilai korelasi dimaksudkan untuk melihat seberapa besar hubungan antara pendidikan karakter $(\mathrm{X})$ tehadap hasil belajar matematika $(\mathrm{Y})$. Untuk menghitung nilai korelasi secara teknis dilakukan dengan bantuan SPSS 20 for window. Hasil analisisnya dapat dilihat pada tabel dibawah ini:

Tabel 3. Model Summary

\begin{tabular}{|c|c|r|r|r|}
\hline Model & \multicolumn{1}{|c|}{$\mathrm{R}$} & R Square & Adjusted R Square & Std. Error of the Estimate \\
\hline 1 & $.738^{\mathrm{a}}$ & .545 & .537 & 3.03491 \\
\hline
\end{tabular}

a. Predictors: (Constant), pendidikan karakter

Berdasarkan hasil analisis statistik diperoleh korelasi antara pendidikan karakter (X) terhadap hasil belajar matematika $(\mathrm{Y})$ sebesar 0,738 angka tersebut menunjukan
tingkat korelasi berada pada tingkat hubungan yang kuat.

b. Menghitung Nilai Koefisien Determinasi

Berdasarkan tabel 3, besarnya korelasi ( $\mathrm{r}$ ) antara kedua variabel amatan tersebut sebesar 0,738 maka didapat koefisien determinasinya $\left(r^{2}\right)$ sebesar 0,545 .

\section{c. Menghitung Keberartian Regresi}

Untuk menghitung keberartian regresi dapat dilakukan menggunakan tabel ANOVA. Secara teknis dilakukan dengan bantuan SPSS 20 for windows dan Hasil analisisnya dapat dilihat pada tabel di bawah ini: 
Tabel 4. ANOVA ${ }^{\mathrm{b}}$

pada siswa Berdasarkan 00; Standar IIPA SMA rikut ini.

antara ghitung w. Hasil

\section{e. Uji Hipotesis}

Hipotesis penelitian ini dimaksudkan untuk mengetahui apakah ada pengaruh positif antara variabel pendidikan karakter $(\mathrm{X})$ terhadap variabel hasil belajar matematika (Y) dengan menggunakan rumus uji-t dan secara teknis dilakukan dengan bantuan program SPSS 20 for windows, dan hasilnya dapat dilihat pada tabel lima. Berdasarkan tabel 5 diperoleh harga $t_{\text {hitung }}$ sebesar 8,338 dan signifikan pada taraf 0,000 karena angka signifikan ini lebih kecil dari angka signifikan yang diberikan $0,00<0,05$ maka pendidikan karakter $(X)$ berpengaruh secara positif terhadap hasil belajar matematika ( $\mathrm{Y}$ ) dalam arti $H_{1}$ ditolak dan $H_{0}$ diterima. 


\section{B. Pembahasan}

Dari hasil analisis deskriptif data menunjukkan bahwa tingkat pendidikan karakter siswa kelas X MIPA SMA Negeri 1 Pasarwajo Tahun Pelajaran 2017/2018 secara umum masih tergolong sedang. Hal ini dapat dilihat pada Tabel 1, dimana skor yang diperoleh siswa tergolong tinggi pada 15\% dengan frekuensi 9 siswa, tergolong sedang pada $70 \%$ dengan frekuensi 42 siswa dan tergolong rendah 15\% dengan frekuensi 9 siswa dari 60 siswa. Minimum $=64,00 ;$ Maksimum $=122,00$, skor rata-rata sebesar 100,0500dan standar deviasi 11,14987.

Tingkat prestasi belajar matematika siswa kelas X MIPA SMA Negeri 1 Pasarwajo Tahun Pelajaran 2017/2018 secara umum masih tergolong sedang. Hal ini dapat dilihat pada Tabel 2, dimana prestasi belajar matematika yang diperoleh siswa tergolong tinggi $13,33 \%$ dengan frekuensi 8 dari 60 siswa, tergolong sedang 60\% dengan frekuensi 36 siswa dari 60 siswa dan tergolong rendah 26,67\% dengan frekuensi 16 siswa dari 60 siswa, Minimum 75, Maksimum $=97$, skor rata-rata sebesar 84,9167 dan standar deviasinya adalah 4,46186. Berdasarkan Tabel 2, hasil belajar matematika siswa kelas X MIPA SMA Negeri 1 Pasarwajo Tahun Pelajaran 2017/2018 merupakan suatu indikasi bagi kita bahwa di antara 60 orang siswa hanya 8 siswa (13,33\%) yang tinggi sementara yang memperoleh kategori sedang dan rendah masing-masing 36 siswa (60\%) dan 16 siswa $(26,67 \%)$. Olehnya itu dalam hal ini, perlu kiranya bagi guru, bagi orang tua siswa dan semua pihak yang terkait di dalamnya agar segera mengambil langkah-langkah atau tindakan-tindakan dalam hal peningkatan hasil belajar khususnya di bidang hasil belajar matematika. Sehubungan dengan ini salah satu tindakan yang perlu dilakukan adalah bagaimana pendidikan karakter siswa harus ditingkatkan khususnya siswa SMA Negeri 1 Pasarwajo untuk meningkatkan hasil belajar matematika siswa.

Berdasarkan persamaan regresi linear $\widehat{Y}=55,355+0,295 \mathrm{X}$ maka diperoleh nilai konstanta sebesar 55,355 dan koefisien sebesar 0,295 ini menunjukkan jika variabel pendidikan karakter dengan koefisien regresi 55,355 naik satu unit maka akan disertai kenaikan hasil belajar matematika pada siswa itu sendiri yang secara rata-rata sebesar 0,295.

Berdasarkan hasil uji $t$ antara variabel pendidikan karakter terhadap hasil belajar matematika diperoleh $t_{\text {hitung }}$ sebesar 8,338 dan signifikan pada 0,000 dimana angka signifikan lebih kecil dari angka signifikansi yang diberikan $(0,000<0,05)$, dengan besarnya koefisien korelasi antara variabel pendidikan karakter terhadap hasil belajar matematika sebesar 0,295 dan koefesien determinasinya 0,545. Maka dapat disimpulkan bahwa pendidikan karakter (X) menjadi salah satu faktor yang mempengaruhi atau menentukan hasil belajar matematika dengan memberikan sumbangan sebesar $54,5 \%$ dan sisanya $45,5 \%$ ditentukan faktor lain yang tidak
diteliti.

\section{KESIMPULAN}

Berdasarkan hasil dan pembahasan penelitian, maka pendidikan karakter (X) memiliki pengaruh yang positif terhadap hasil belajar matematika pada siswa kelas X SMA Negeri 1
Pasarwajo

\section{DAFTAR PUSTAKA}

Agus, Wibowo. (2012). Pendidikan Karakter. Jogjakarta: Pustaka Pelajar.

Arikunto, Suharsimi. (2002). Dasar-dasar Evaluasi Pendidikan. Jakarta: Bumi Aksara. 
Aunnurahman. (2010). Belajar dan Pembelajaran. Cetakan Keempat. Bandung: Alfabeta.

Anton, Suwito. (2012). Dasar-dasar dan Proses Pembejaran Matematika 1. Semarang. FMIPA UNNES.

Furqon Hidayatullah. (2010). Pendidikan Karakter: Membangun Peradaban Bangsa. Surakarta: UNS Press.

Galih Jatmiko. (2014). Implementasi Pendidikan Karakter pada Siswa Kelas X SMK Piri I Yogyakarta Jumisan Teknik Kendaraan Ringan Tahun Ajaran 2013/2014. UNY Yogyakarta.

Harning Satyo. (2005). Pengaruh Disiplin Belajar: Lingkungan Keluarga dan Lingkungan Sekolah terhadap Prestasi Belajar Siswa Kelas X Semester I Tahun Ajaran 2004/2005 SMAN Gemolong Kabupaten Sragen. Skripsi. UNNES Semarang.

Jamal, Ma'mur, Asmani. (2013). Buku Panduan Internalisasi Pendidikan Karakter di Sekolah. Cetakan keenam. Jogjakarta: DIVE press (Anggota IKAPI).

Mendiknas. (2010). Penerapan Pendidikan Karakter Dimulai dari SD. Diakses dari http://antarnews.com/berita/1273933824/mendiknas. Tanggal 23 Februari 2017.

Maya, Umami. (2013). Pengaruh Character Learning Education terhadap Hasil Belajar Matematika.

Ovy, Yuliana. (2013). Pendidikan Karakter pada Prosedur Pembelajaran Matematika Kelas X SMA Negeri 1 Jumawa Kabupaten Pati. Semarang: Universitas Negeri Semarang.

Siswa Kelas VII SMP Negeri 1 Baubau. Baubau: Universitas Dayanu Ikhsanuddin.

Sriyanto, H.J. (2007). EasyMath. Yogyakarta: Penerbit Pustaka Widyatama.

Yeni, Nuraini, Zain. (2012). Pengaruh Kebiasaan Belajar dan Prestasi Siswa tentang Pembelajaran Guru Matematika terhadap Prestasi Belajar Matematika.

emiliki

egeri 1 